\title{
Network and Entrepreneurial Explorative Learning Development as an Attempt to Improve the Performance of Micro, Small and Medium Enterprises
}

\author{
Nurul Huda* \\ Institute of Economic Science Bima \\ (STIE Bima) \\ Bima, Indonesia \\ nurulhuda.stiebima@gmail.com
}

\author{
Ismunandar Ismunandar \\ Institute of Economic Science Bima \\ (STIE Bima) \\ Bima, Indonesia \\ andar.stiebima@gmail.com
}

\author{
Sri Syamsinirwani \\ Institute of Economic Science Bima \\ (STIE Bima) \\ Bima, Indonesia \\ Srisyamsinirwani.stiebima@gmail.com
}

\author{
Muhammad Yusuf \\ Institute of Economic Science Bima (STIE Bima) \\ Bima, Indonesia \\ yusufzm.stiebima@gmail.com
}

\author{
Aris Munandar \\ Institute of Economic Science Bima (STIE Bima) \\ Bima, Indonesia \\ sriernawati.stiebima@gmail.com
}

\begin{abstract}
Micro, Small and Medium Enterprises (MSMEs) are the economic sector that has the best resilience. The ability of MSMEs needs to be empowered and developed continuously by trying to reduce existing obstacles. This research was conducted at MSMEs in the City of Bima for seven months. The method of this research involves explanatory research by using a sample survey approach. Conventionally, explanatory research is used to explain the relationship between variables through hypothesis testing. The questionnaire was distributed to 104 MSMEs in the City of Bima in which the validity and reliability of the questionnaire were tested and processed by using SPSS so that the analysis can be more accurate and reliable. The results indicate that entrepreneurial networks affect the performance of MSMEs in the City of Bima, while exploration learning does not affect the performance of MSMEs in the City of Bima. In addition, entrepreneurial network has a dominant effect on the performance of MSMEs in the City of Bima.
\end{abstract}

Keywords - exploration learning, entrepreneurial network, MSMEes performance

\section{INTRODUCTION}

During the economic crisis that took place in Indonesia, Micro, (MSMEs) were the economic sector that had the best resilience. The ability of MSMEs needs to be empowered and developed continuously by trying to reduce existing obstacles. MSMEs face many problems both internally and externally that make MSMEs have not been able to contribute optimally like other economic sectors. One of the problems is the low quality of human resources so that its management has an impact on competitiveness and the ability to break through market share. Empowerment and development of MSMEs through the reduction of obstacles faced needs to be done to make a maximum contribution to the improvement of community welfare.
There are several problems in developing MSMEs in various sectors, namely weak capital structure and access to capital sources, availability of raw materials and its continuity, limited ability in technological mastery, weak organization, and business management, and lack of quality and quantity of human resources which make the network of business partnerships between banking, Government, higher education, research institutes and research centers are very much needed in order to improve quality and performance of Micro, Small and Medium Enterprises (MSMEs).

Theoretical contradictions found in some research literatures indicate the existence of a research gap. Some stated that business networking has a positive influence on company performance, while several other research states that business networking has no influence on company performance In addition, there are also different opinions regarding explorative learning in which it has a negative and positive effect on the performance of MSMEs, and whether entrepreneurial networks and explorative learning have a significant positive effect on MSME performance [1]-[4].

Rerlecting to the time of monetary crisis in which the MSME has the best level of resilience, it is necessary to find solutions to solve all the obstacles that are still experienced by MSMEs. One alternative solution is the need for the development of entrepreneurial networks and explorative learning that play an important role in the economic empowerment of the community as a full implementer of MSME product marketing that will connect MSMEs with related parties to improve the performance and welfare of MSMEs.

The long-term target to be achieved is to improve the performance of MSMEs throughout the City of Bima with an entrepreneurial network. The specific target is to 
improve the performance of MSMEs throughout the City of Bima by implementing entrepreneurial networks. The targetted output of entrepreneurial networks for MSMEs is to obtain an entrepreneurial networking model that will be applied to support the improvement of MSME illustrated by the improvement of learning capacity through explorative learning of human resources.

The problems raised in this study are (1) Does entrepreneurial network influence the performance of MSMEs in the City of Bima, (2) Does explorative learning affect the performance of MSMEs in the City of Bima, (3) which entrepreneurial networking and explorative learning variables have a dominant influence on the performance of MSMEs in the City of Bima [2].

\section{LITERATURE REVIEW}

\section{A. The Development of a Networking Framework}

According to Groen, the development of a multidimensional framework which in line with the goals of entrepreneurial research is inspired by Parsons' work which explains there are 4 mechanisms inherent in this definition, namely [5]:

- Interaction between players

- Atempts to achieve targets

- Optimization processes

- Maintain cultural patterns and provide symbols

Four Dimensions of the Development of Networking Framework are:

- Scope

- Scale

- Skill \& Value

- Social Networking

\section{B. Explorative Learning}

Explorative Learning is an activity that includes employee internal training, skills and knowledge sharing to improve the quality of human resources and products. Thus, it is very important to have cooperation with business training institutions to develop knowledge such as small and large companies, fostered institutions, universities, research institutions, research centers to exchange experiences and research results. Organizations that put more emphasis on responsiveness and knowledge management will improve team learning, and in turn, team learning improves task performance and the quality of interpersonal relationships positively [6].

\section{Company Performance}

The Measurement of company performance is based on the company's financial gain. Some are based on the entrepreneurial process to produce outcomes that are different in various new dimensions. Performance measurement of small and medium-sized companies has not been well defined, so that in some studies many used aspects of measurement that are less important [7].
Company performance can be seen from the dimensions of growth and is associated with finance which can be linked to past company performance. For example, sales growth and market growth are traditionally used to measure performance. The second dimension is observing aspects of current company performance events. This relates to non-financial aspects which are still vital for the company such as aspects of performance.

\section{RESEARCH METHOD}

This research is quantitative research with an explanatory method. The instrument used was a questionnaire that was distributed to MSMEs from various sectors. The analytical tool used was the SPSS program. The populations of this study were the overall MSMEs from various economic sectors in the city of Bima with a total of 6632 MSMEs. Because the number of MSMEs in the City of Bima was very large and there were limitations in investigating all MSMEs, sampling was done. The number of samples used was 104 respondents so that the data could be more representative. The purposive sampling was used by setting up specific characteristics which in line with the objectives of the research so that it is expected to answer the research problem. The research hypothesis are as follows:

H1 : The entrepreneurial network affects the performance of MSMEs in the City of Bima.

$\mathrm{H} 2$ : Exploration learning affects the performance of MSMEs in the City of Bima.

H3 : Entrepreneurship network and exploration learning dominant influence on improving the performance of MSMEs in the City of Bima

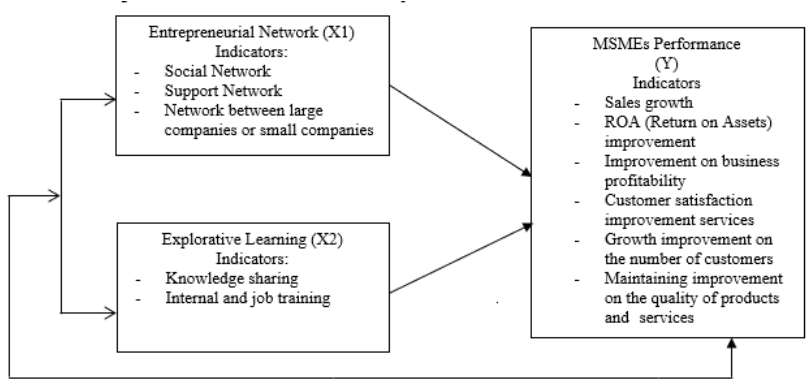

Fig. 1. Research Framework

\section{RESULTS AND DISCUSSION}

\section{A. Results of Hypotheses Test}

To find out whether the hypotheses in this study are accepted or rejected, hypotheses test was performed using the t-test. The results of the hypotheses test are explained as follows:

TABLE I. T-TEST

\begin{tabular}{|c|c|c|c|}
\hline \multicolumn{4}{|c|}{ Coefficients $^{\mathrm{a}}$} \\
\hline Model & $\begin{array}{c}\text { Unstandardized } \\
\text { Coefficients }\end{array}$ & $\mathrm{T}$ & Sig. \\
\hline
\end{tabular}




\begin{tabular}{|l|c|c|c|c|c|}
\hline & \multicolumn{1}{|c|}{ B } & $\begin{array}{c}\text { Std. } \\
\text { Error }\end{array}$ & \multicolumn{1}{|c|}{ Beta } & & \\
\hline Constant) & 19.089 & 1.666 & & 11.460 & 000 \\
\hline $\begin{array}{l}\text { Entrepreneurial } \\
\text { Network }\end{array}$ & .104 & .349 & 3.762 & .000 \\
\hline $\begin{array}{l}\text { Explorative } \\
\text { Learning }\end{array}$ & .188 & .155 & .113 & 1.214 & .227 \\
\hline a. Dependent Variable: MSMEs & & & \\
\hline
\end{tabular}

Source: Processed Data 2019

\section{B. The Effect of Entrepreneurial Networks on MSME Performance in the City of Bima.}

The results of the $\mathrm{t}$-test for this variable indicate that $\mathrm{t}$ test is 3.762 while the $t$-table is $1.983(3.762<1.983)$ with a significance value of 0.000 which is less than 0.05 (0.000<0.05), $\alpha=5 \%: 2=2.5 \%$ (two-sided test) then Hypothesis 1 is accepted (The Entrepreneurial Network influences the performance of MSMEs in the City of Bima). This means that the higher or wider entrepreneurial network, the better performance of MSMEs. Thus, the companies that manage entrepreneurial networks to the maximum are able to create 'value-added' and 'competitive advantages' that lead to an improvement in MSMEs performance. This result is in line with findings which state that information and knowledge accelerate better understanding of developing strong and flexible relationships with customers, as well as with other members of the supplier chain [7]. A closer relationship with suppliers will make a strong contribution to the company's performance, including cost efficiency, quality improvement, reliability, and filling input needs which are always available at any time.

\section{The Effect of Entrepreneurial Networks on MSMEs Performance in the City of Bima}

The results of the t-test statistics for this variable indicates that $\mathrm{t}$-test is 1.214 with the $\mathrm{t}$-table of 1.983 (1. $214>1.983$ ) and a significance value of 0.227 which is greater than $0.05(0.227>0.05), \alpha=5 \%: 2=2.5 \%$ (Twosided test), hence Hypothesis 2 is rejected which implies that exploration learning does not affect the performance of MSMEs in the City of Bima. This result contradicts the research conducted by Shinta Wahyu in her organizational research that emphasizes responsiveness and managing knowledge will improve team learning, and in turn, team learning positively influences task performance and the quality of interpersonal relations [8]. This indicates that the MSMEs in the City of Bima have not optimally received exploration learning.

\section{The Dominant Effect of Entrepreneurial Networks and Exploration Learning on Improving MSMEs Performance in the City of Bima.}

It can be seen from the results of this research that in order to determine the most dominant independent variable on the performance of MSMEs, the smallest significance value need to be seen. Therefore, the variable that has a dominant influence on MSMEs performance is the entrepreneurial network with the smallest significance value (0.000).

\section{CONCLUSION}

The conclusions of this research are as follows: The entrepreneurial network affects the performance of MSMEs in the City of Bima while exploration learning does not affect the performance of MSMEs in the City of Bima. The support of a strong entrepreneurial network will increase the performance of MSMEs which means that the company that manages the entrepreneurial network to its full potential is able to create 'value-added' and 'competitive advantages' that will lead to an improvement on MSME performance in the City of Bima. The support of a strong entrepreneurial network will increase the performance of MSMEs which means that the company that manages the entrepreneurial network to its full potential is able to create 'value-added' and 'competitive advantages' that will lead to an improvement on MSME performance in the City of Bima. The entrepreneurial network has a dominant influence on the performance of MSMEs in the City of Bima.

\section{REFERENCES}

[1] B. Batjargal, "Effects of networks on entrepreneurial performance in a transition economy: The case of Russia," Front. Entrep. Res., vol. 2000, pp. 97-110, 2000.

[2] H. E. Aldrich and T. Baker, "Blinded by the cites? Has there been progress in entrepreneurship research," Entrepreneurship, vol. 377400, 2000.

[3] L. S. Atmaja, "Statistika untuk bisnis dan ekonomi," Yogyakarta Penerbit Andi, 2009.

[4] C. W. Emory and D. R. Cooper, "Business Research Methods, Homewood: Irwin. Ensley, MD, Carland, LC, Carland, JW, and Bank, M (1999). Exploring the Existence of Entrepreneural Teams," Int. J. Manag., vol. 16, pp. 276-286, 2000 .

[5] A. J. Groen, "Knowledge intensive entrepreneurship in networks: towards a multi-level/multi dimensional approach," J. Enterprising Cult., vol. 13, no. 01, pp. 69-88, 2005.

[6] Sakdiyah, "Pengaruh Kompetensi, Lingkungan Makro dan Jejaring Usaha terhadap Kinerja Usaha Mikro Kecil dan Menengah (UMKM) Makanan di Kecamatan Kalinyaman Kabupaten Jepara,” J. Econ., vol. 2, no. 3, 2017.

[7] M. Zellmer-Bruhn and C. Gibson, "Multinational organization context: Implications for team learning and performance," Acad. Manag. J., vol. 49, no. 3, pp. 501-518, 2006.

[8] Shinta Wahyu, "Faktor-faktor yang Mempengaruhi Kinerja Usaha Mikro Kecil Menengah (UMKM) di Kota Batam," $J$. Econ., vol. 1, 2017. 